\title{
DETERMINANT OF TAX AGGRESSIVENESS AND RELATIONSHIP WITH FIRM VALUE (EMPIRICAL STUDY COMPANY LISTED GO-PUBLIC IN INDONESIA STOCK EXCHANGE)
}

\author{
Akhmad Hitten* \\ Universitas Tanjungpura, Indonesia \\ Novita \\ Universitas Tanjungpura, Indonesia
}

\begin{abstract}
This study aims to determine the effect of liquidity, profitability, and solvability on the level of tax aggressiveness with firm value as a control variable. Total sample was 86 non-financial company that implicate tax aggressiveness in Indonesia Stock Exchange (IDX), with purposive sampling, with cross section data period 2007 to 2017. This study using agency theory and signaling theory as the grand theory. The data were analyzed using Structural Equation Modeling- Partial Least Square (SEM-PLS). This study uses a SmartPLS 3.0 and must pass outer and inner criteria. The reason why the author choose SmartPLS is because this application program can explain each indicator of the variable, so will be easy to evaluate which indicator that not have the correspondent affect with the dependend variable. The previous studies of ETR showed inconsistent results in various countries. Test results show that liquidity and profitability have a negative and significant influenced with tax aggressiveness. Solvability has a negative and not significant influenced on tax aggressiveness. Firm value has a positive and significant influenced on tax aggressiveness.
\end{abstract}

JEL : F12, F30, F39

Keywords : liquidity, profitability, solvability, ETR, and firm value.

\begin{abstract}
ABSTRAK
Penelitian ini bertujuan untuk mengetahui pengaruh dari likuiditas, profitabilitas, dan solvabilitas terhadap tingkat agresivitas pajak dengan nilai perusahaan sebagai variabel kontrol. Jumlah sampel adalah 86 perusahaan non keuangan yang berimplikasi agresivitas pajak di Bursa Efek Indonesia (BEI), dengan menggunakan teknik purposive sampling pada data cross section periode 2007 hingga 2017. Penelitian ini menggunakan teori agency dan teori signaling sebagai teori dasar dalam penelitian ini. Analisis data menggunakan Structural Equation Modeling-Partial Least Square (SEM-PLS). Studi ini menggunakan SmartPLS 3.0 dan harus melalui analisis outer model dan inner model. Alasan penulis memilih SmartPLS adalah karena program aplikasi ini dapat menjelaskan masing-masing indikator variabel, sehingga akan mudah untuk mengevaluasi indikator mana yang tidak berpengaruh secara koresponden terhadap variabel dependen. Penelitian sebelumnya menunjukkan variabel ETR menunjukkan hasil yang tidak konsisten pada berbagai negara. Hasil pengujian menunjukkan bahwa likuiditas dan profitabilitas berpengaruh negatif dan signifikan terhadap agresivitas pajak. Solvabilitas berpengaruh negatif dan tidak signifikan terhadap agresivitas pajak. Nilai perusahaan berpengaruh positif dan signifikan terhadap agresivitas pajak.
\end{abstract}

Kata Kunci : likuiditas, profitabilitas, solvabilitas, ETR, dan nilai perusahaan.

\section{INTRODUCTION}

Since 29 years ago, tax aggressiveness already be the view in the firm. Because of reformation, United states found evidence of tax evasion in 1986 that has an effect on tax obligations, both activities allowed by tax or special activities to reduce taxes (Desai \& Dharmapala, 2009). In practice, tax aggressiveness is an activity to exploit the weaknesses of tax law without existing tax laws, that activities carried out by companies can interpret as a transfer of

\footnotetext{
*Email : akhmadhiten@gmail.com

Received : 07-07-2020, Accepted: 28-08-2020, Published : 28-08-2020

P-ISSN : 2087-9954, E-ISSN : 2550-0066. DOI: http://dx.doi.org/10.26418/jebik.v9i2.41245
} 
asset from the government to companies, which can increase value of the company. Tax aggressiveness behavior is certainly by reducing corporate taxes but in ways that are still allowed in existing tax regulations, so later will increase profits and have an impact on the value of the company. According Blouin (2014) to optimization of corporate value which is a company goal can be achieved through the implementation of financial management functions, where financial decision will have an impact on firm value, where one manager's decision regarding this matter is behavior tax aggressiveness.

According to Fama \& French (1998), tax aggressiveness is an act of manipulating tax income that company does through action tax planning, using legally methods (tax aggressiveness) or illegal (tax evasion). Although not all actions are taken breaking the rules, but more gap used by the company considered more aggressive towards taxes. Tax aggressiveness can be done because there is an opportunity for taxpayers to delay payments, there are differences the rate between tax income and special transactions and the difference in tax treatment due to differences in transaction characteristics. Differences in tax treatment can arise because the characteristics of different financial instruments give rise to different tax treatment. This disparate tax treatment can be utilized by the company to carry out tax aggressiveness with hedging transactions. Different characteristics also have the potential to be used to carry out tax aggressiveness on funding decisions (Kamila, 2014). Because of debt cost in the form of interest deductible from taxable income while costs equity in the form of dividends is not an object of tax, the company can take advantage of these differences to carry out tax aggressiveness (Sukmawati \& Rebecca, 2016). In addition accrual accounting gives discretion management to obtain do earnings management (Waegenaere, Sansing, \& Wielhouwer, 2013).

There have several studies that have tried to examine tax compliance and tax aggressiveness, including ownership (Chen, Chen, Cheng, \& Shevlin, 2010; Sari \& Martani, 2010), agency problem (Lanis \& Richardson, 2011), corporate governance (Sartori, 2010; Sari \& Martani, 2010), independent directors (Lanis \& Richardson, 2011). These studies intended so that the implementation of the tax system can be more effective and efficient in line with the development of the business world. Therefore, additional research support is needed regarding corporate tax aggressiveness. For measuring tax avoidance with ETR (Effective Tax Rate) is calculated by means of income tax. ETR is expected to provide a complete picture of the tax burden will have an impact on accounting profit which can be seen in the report corporate finance. Companies that have a low ETR will try to increase ETR by low profits because companies tend to want lower profits to avoid the possibility of paying taxes in future so companies can make policies on the accrual contained in the deferred tax expense becomes smaller. Deferred tax expense is a multiplication of temporary differences with applicable tax rates.

A company's liquidity is predicted will affect tax aggressiveness. Companies that have high liquidity describe company have good cash flow to pay all obligations include tax with applicable rules. Companies have low liquidity will disobey taxes to maintain company cash flow rather than pay tax. Level of solvability on go public manufacture companies at Indonesia tends to increase because of debt interest will reduce taxable income. Companies who have high tax obligations will have high debt too, so the company intentionally high debt to reduce the tax burden (Widjaja, Djumena, \& Yuniarwati, 2017). The higher profitability, the company will get a high tax burden (Darmadi \& Zulaikha, 2013). The reason is because tax income will be imposed based on the amount of income received by the company. Companies that have high profitability have a low 
tax burden. This is because tax will reduce company profits, so the company will carry out strategies to reduce its tax. Because there are differences in the results of existing research, this study is need to overcome this problem. The goal of each entity is with higher of firm value. The firm value is reflected in the market price of the company's stock (Fama \& French, 1998). The higher market price of a company's stock will increase the prosperity of its shareholders (Brigham, 2018). This can be have the attractiveness of potential investors to invest their capital in these entities.

Firm value is a form of public trust in the company. When the firm value increase will be realized if there goals and interests between managers and principal. The principal requires management to manage their company well and achieve the determined targets in order to increase the value of their company. However, it is not uncommon for managers to have different interests and goals, so the principal's interests are neglected. This can have conflict between two parties which is often referred as agency conflict (Chen, Hu, Wang, \& Tang, 2014). The cause of agency conflict due to assymmetry information between manager and shareholders. Managers tend to prioritize act their own interests rather than prioritizing the interests of principal, so the decisions taken by management can affect the firm value either positively or negatively (Jensen \& Meckling, 1976).

The research is different from previous studies because there are development in the firm value as the variable control component section additional periods all IPO companies because competition in trade had implemented a lot of tax aggressiveness from period 2007-2017, as well as to examine the result different from previous research. In measuring tax aggressiveness, this study uses a Effective Tax Rate (ETR). Based on existing research gaps, and the phenomena, the authors are compelled to research again and find out what factors influence tax aggressiveness, by developing previous studies with the addition of the firm value. This study entitled "Determinant of Tax Aggressiveness (Empirical Study on Companies Listed on the Indonesia Stock Exchange)".

\section{LITERATURE REVIEW}

\subsection{Agency Theory}

Agency theory and signaling theory be the grand theory in this research. Agency theory explain the existence of conflicts that will arise between the owner and management company. This conflict is called agency problem (Jensen \& Meckling, 1976). Agency problems occur between tax collectors and taxpayers. The Fiscal hope will be as much income as possible from tax collection, while from the management's view the company must increase profits with low tax burden. From this different point of view causes conflicts between the tax authorities as tax collectors with taxpayer of the company. The difference in interests between the principle and the agent can affect various things related to the performance of the company, one of which is the company's policy on corporate tax.

When the principal delegate the management to do for fulfill the principal's interests and have one part which has more information than other parties, then it happens asymmetry information. There are two conditions that cause the occurence of asymetry information, namely moral hazard and adverse selection. Agency conflicts can cause companies to incur more costs, called agency costs. Agency theory in this study can show the existence of asymmetry information if there is a conflict of interest when taking action in tax aggressiveness. In general, company with 
higher assets, stake holder attention will tend to be tighter in supervise these companies so that impact of the conflict in interest can be minimized and provide good value for company.

Taxation system in Indonesia using self-assessment system which company can calculate and report its own tax. The tax authorities act as principals in relations the agency. In an effort to protect its interests, the taxpayer will strive for various businesses with aim to minimizing tax burden. This can be done by legal or illegal (Putra, Syah, \& Sriwedari, 2018). This system can provide an opportunity for agents to manipulate income to be lower so the tax burden on company becomes smaller. This is done by the agent because of the asymmetrical information with the principle so the agent can take advantage of it cooperation agreement independently with the principle. There are several ways to control the actions of agents related to tax management activities, namely by evaluate the results of the company's financial statements using financial ratios compared to the actions of tax aggressiveness that agent might do.

\subsection{Signaling Theory}

Signaling theory emphasizes the importance of providing information from internal to external parties or investors used as investment considerations tools. Internal part of the company in general have the better and quickly information compare the external part, like investor. Individual make decisions based on public information like freely available and private information. Insider obtain positive and negative private information, and must decide wheter The shareholder want company have to communicate the information to outsider (Connelly, Certo, Ireland, \& Reutzel, 2011). Information on net income is the main focus can describe the company value, so indirectly managers are required to increase net income by tax aggressiveness. Tax evasion will increase company value when viewed from manager's perspective, but in shareholder perspective will incur additional costs in future such as costs incurred for tax planning and other fees that might arise due to tax aggressiveness behaviors.

The main assumption in this theory is management has accurate information about the value of the firm that does not known by outside investors and management be the people who always try maximizing expected incentives. Desire management to maximize these incentives make it not fully convey all the information because of that might affect the value of the company. This will cause to happen asymetric information. Asymmetric information can make it difficult for investors to assess company quality. As a result, investors will give a rating not good for all companies. This tendency is called pooling equilibrium because good or poor quality companies. To overcome this asymmetric information problem, firm will give the market information in general that can be respounded as the signal. For the external part, like investor the financial statement of the company can be the signal to making investment decision.

\subsection{Liquidity}

Companies with high liquidity ratios indicate the company's ability to meet lower level requirements, which shows the company with financial conditions and easily sells its assets if needed (Suyanto \& Supramono, 2012). Companies that have high liquidity ratios are called liquid companies. Liquidity problems are one of the important problems in a company that relatively difficult to solve. Companies with high profit do not guarantee good liquidity. It because profit ratio is calculated from accounting profit divided by investment, assets, or equity, where accounting profit is obtained by accrual basis. 
Liquidity problems can cause companies to regulate licensing so they can achieve a transition to tax corporate. The reason is companies are more concerned with cash flow to pay high tax. The results of tax savings can be used by companies to their short-term needs. Liquidity shows the ability of company to meet financial needs that must be approved, or whether a company meets the billed financial needs (Anita, Basri, \& Julita, 2015). The meaning of liquidity firm, which is related to outside part or creditors, is called "business entity liquidity," which is called liquid firm, means the company must pay attention whether the company can pay every time the payment is need for company to pay labor costs, etc. In other words, it can be agreed upon by the liquidity that exists between the amount of cash and other assets that can be equated with cash with the current amount of money and expenses for the company. Based on this description, the hypothesis is formulated as follows: liquidity has a negative influence on tax aggressiveness.

\subsection{Solvability}

Pecking order theory describes companies with high levels of solvability will explain complete information in financial statements as a way to avoid cost of monitoring by investors compared to companies with low solvability (Anita et al., 2015). Solvability using sources of funds that have a fix charge hope to increase than the fixed costs of shareholders. Solvability on the company can have the effect for small amount of tax approved by the company. This is because the interest costs of the results can be deducted in tax so the tax becomes smaller. Interest costs can increase tax costs and solvability will cause the ETR be smaller. Furthermore, Gupta \& Newberry (1997) also found a negative relationship between tax aggressiveness with ETR and solvability. As long as inventory intensity is a substitute for capital intensity, intensive inventory of firms must have a higher ETR (Zimmerman, 1983). Gupta \& Newberry (1997) provided evidence that firms with larger proportions of fixed assets have lower ETR due to tax incentives, while firms with larger inventory proportions have a higher ETR.

Positive Accounting Theory with the debt agreement hypothesis explains the company's relationship with creditors higher than the company will be more profitable current period with the aim of believing the company to increases the higher profit with creditors by continuity reason of external capital loans. Companies with high levels of solvability will not be aggressive in terms of taxation because companies must maintain their profits because they succeed with the interests of creditors. When a company increases revenue, the tax income returned will also increase. Modigliani \& Miller (1958) state the company will increase with increasing returns because the effects of corporate tax. This is because in perfect market conditions and generally paid interest of debt can be used to increase tax income. Thus, there are two companies with the same operating profit, but one company uses debt and pays interest, while the company pays interest will pay a smaller tax income, then saving income. This ratio shows the comparison between the debt provided by the company owner. Based on this description, the hypothesis is formulated as follows: solvability has a negative influence on tax aggressiveness.

\subsection{Profitability}

Agency theory explains things that can increase company profits. Profitability describe profit generates a company through all available resource capabilities such as sales activities, cash, capital, number of employees, number of branches, etc. Profitability is related to net income and tax income for companies. When profits increase, the amount of income will increase according to the increase in company profits. Companies that have a high level of profit can attract investors to 
invest because the management company that operational company successfully. If the company has a low level profit so investors choose did not to invest in capital.

This statement supports signaling theory which states investors will be interest in investing because the higher profitability. Companies that have high profits will have the opportunity to tax liabilities position (Yusuf, Yunus, \& Supaat, 2013). Companies that have optimal tax planning, results for companies that want tax will decrease (Nugraha \& Meiranto, 2015). Based on this description, the hypothesis is formulated as follows: profitability has a negative influence on tax aggressiveness.

\subsection{Firm Value}

Agency theory can explain the role of tax aggressiveness on firm value. Delegation of authority by the principal to agent will require the agent to provide the best possible performance to improve the performance of the company. Therefore, management strives to manage the company's finances well and efficiently. One of the efficiency measures taken is to minimize tax burden, which is considered to reduce the company's economic capability. So that management is motivated to do tax to minimize tax of the company, so the company's profits are expected to increase which can have an impact on increasing firm value. With increase firm value, of course it will attract investors to invest in the company. This supports signaling theory pioneered by Ross (1977). Companies can reduce the tax value that must be paid by increasing debt by the company so firm value will increase in accordance with the theory of Modigliani Miller. Based on this description, the hypothesis is formulated as follows: tax aggressiveness has a positive influence on firm value.

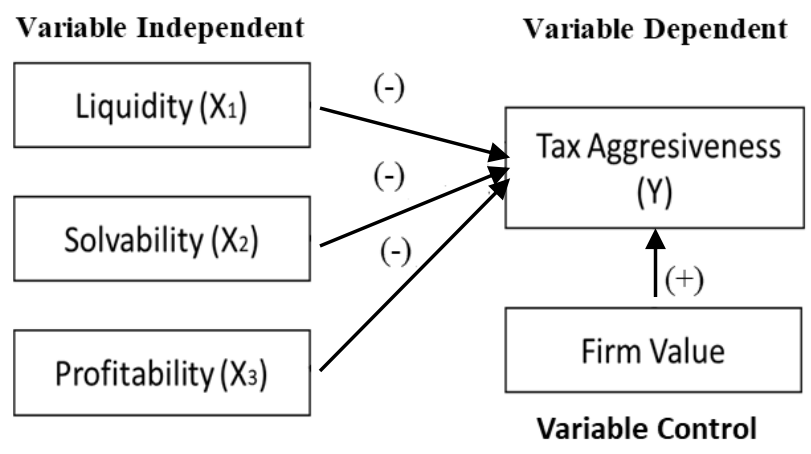

Figure 1. Conceptual Framework

\section{RESEARCH METHODOLOGY}

The population in this study are all IPO companies listed on IDX, which amount of 105 companies from 2007-2017. The sampling with purposive sampling technique, with certain criteria, so companies in the population are the sample. The first criterion is that companies that be sample are profit companies in period 2005-2017 but not include companies classified as high-regulation industries such as public utilities, banks that have high debt-equity are equivalent to the high-risk inherently related industries to non-regulated firms (Jensen \& Meckling, 1976). The second criterion is the issuance of financial statements that are not completed during the observation period. On the basis of some criteria above, 86 companies were obtained as a sample. This study uses 
secondary data in the form of financial statements and market data obtained through several documents, especially Indonesian Stock Exchange (IDX).

The independent variable in this study are liquidity, solvability, and profitability. The dependent variable is tax aggressiveness. The variable control in this study is firm value. With cross-section data, Structural Equation Model (SEM) is used with the SmartPLS program for hypothesis testing and be the the novelty of this study. The reason why the author choose SmartPLS is because this application program can explain each indicator of the variable, so will be easy to evaluate which indicator that not have the correspondent affect with the dependend variable. The multiple regression from this research is:

$E T R=\beta_{0}+\beta_{1 \text { LIQUIDITY }}+\beta_{2 \text { SOLVABILITY }}+\beta_{3 \text { PROFITABILITY }}+\varepsilon t$.

FIRM VALUE $=\beta_{0}+\beta_{4 E T R}+\varepsilon t$.

Note:

ETR $=$ effective tax rate of 10 years in period $t$,

LIQUIDITY $=$ liquidity in period $\mathrm{t}$,

SOLVABILITY $=$ solvability in period $\mathrm{t}$,

PROFITABILITY $=$ profatibily in period $t$,

FIRM VALUE $=$ firm value in period $\mathrm{t}$,

$\beta_{0}$ $=$ intercept,

$\varepsilon t$ $=$ error.

Structural equation analysis based on variance which can simultaneously perform measurement model testing as well as structural model testing. The measurement model is used to test validity and reliability, while the structural model is used to test casuality (testing hypotheses with prediction models). Outer model is often also called outer relation or measurement model that defines how each indicator block is related to its latent variables. The measurement model (outer model) is used to test construct validity and instrument reliability. Validity testing is done to determine the ability of research instruments to measure what should be measured. Furthermore, the reliability test can be seen from the Crombach's alpha and value of composite reliability. To be able to say a statement item is reliable, then the Cronbach's alpha value must be $>0.6$ and the composite reliability value must be $>0.7$.

The structural model is for predicting causality relationship with latent variables. Through the bootstrapping process, parameters T-statistic test was obtained to predict the existence of causality relationship. Model structural is evaluated by looking at the percentage variance explained by the value of $\mathrm{R}^{2}$ for the dependent variable using the size of the Stone-Geisser Q-square test and also looking at the magnitude of the structural path coefficient. The significance of hypothesis support can be used to compare the T-table values and T-statistics. If the T-statistic is higher than the T-table value it means hypothesis supported or accepted. In this study, the level of confidence is $95 \%$ (alpha 95\%). 
Table 1. Operational Variable

\begin{tabular}{|c|c|c|}
\hline Variable & Indicator & Formula \\
\hline \multirow{4}{*}{ Liquidity } & Current Ratio (CR) & $\mathrm{CR}=\frac{\text { Current Assets }}{\text { Current Liability }}$ \\
\hline & Ouick Ratio (OR) & $\mathrm{OR}=\underline{\text { Current Assets-Inventory }}$ \\
\hline & & $\begin{array}{l}\text { Current Liability } \\
\quad \text { Net Sales }\end{array}$ \\
\hline & Casn r urnover Katio (C IK) & Uet Working Capital \\
\hline \multirow{3}{*}{ Solvability } & Debt to Asset Ratio (DAR) & $\mathrm{DAR}=\frac{\text { Total Debt }}{\text { Total Asset }}$ \\
\hline & Debt to Equity Ratio (DER) & DER $=\frac{\text { Total Debt }}{\text { Total Equity }}$ \\
\hline & Long Term Debt Ratio (LTD) & $\mathrm{LTD}=\frac{\text { Long Term Debt }}{\text { Total Equity }}$ \\
\hline \multirow{3}{*}{ Profitability } & Basic Earning Power (BEP) & $\mathrm{BEP}=\frac{\text { EBIT }}{\text { Total Assets }}$ \\
\hline & Gross Profit Margin (GPM) & $\mathrm{CR}=\frac{\text { Gross Profit }}{\text { Revenue }}$ \\
\hline & Net Profit Margin (NPM) & $\mathrm{NPM}=\frac{\text { Net Revenue }}{\text { Net Sales }}$ \\
\hline Tax & Effective Tax Rate (ETR) & $\mathrm{ETR}=\frac{\text { Total Tax Expense }}{\text { Taxable Income }}$ \\
\hline Firm Value & Tobin Q & $\mathrm{Q}=\frac{\text { Market Value }}{\text { Assets value }}$ \\
\hline
\end{tabular}

\section{RESULT AND DISCUSSION}

SEM based on variance measurement model testing as well as structural model testing. The measurement model is used to test validity and reliability, while the structural model is used to test casuality. The first model in the research is outer model with formative indicators was evaluated by convergent and discriminant validity from the indicator and composite reliability for indicator blocks (Ghozali, 2013).

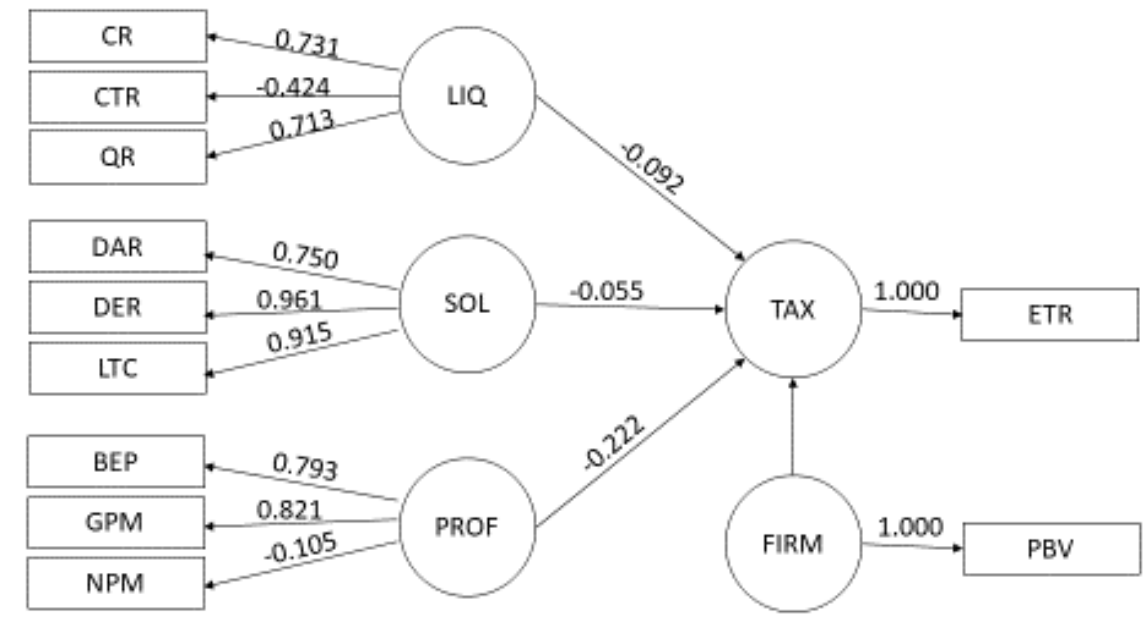

Figure 2. Convergent Validality

From the Figure 1, show the test of convergent validality, liquidity show that CTR and profitability also show NPM don't meet the category of outer loading. Both of that indicator for the outer loading $<0,70$. So both of the indicator must be executed. So the final figure can be seen in the Figure 2. 


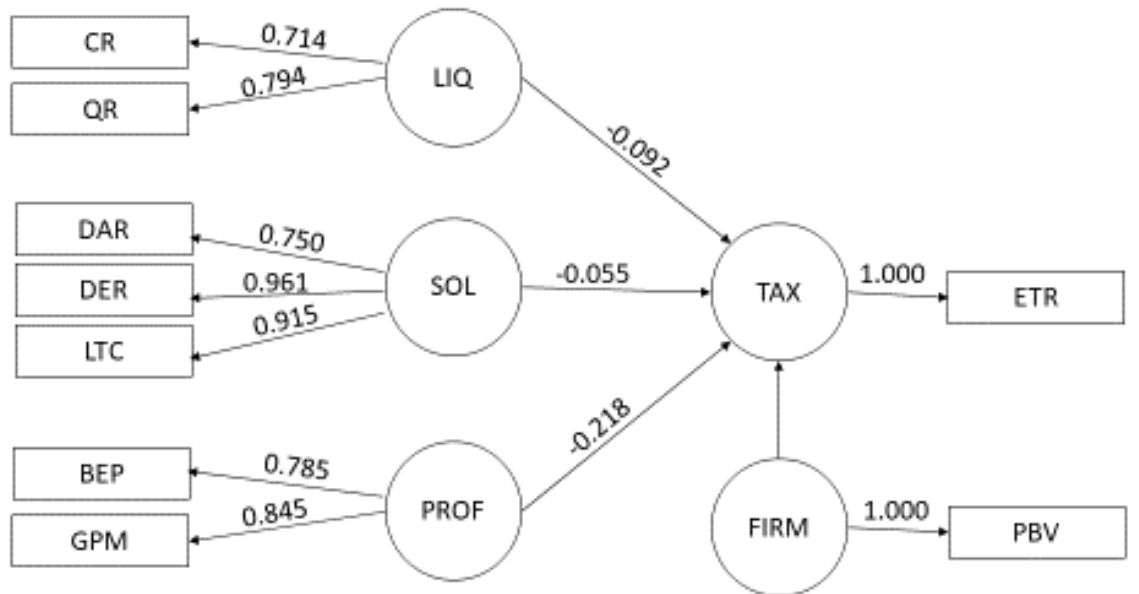

Figure 3. Convergent Validality

Based on the measurement model above, all indicators are analysis of research variables with a loading factor greater than 0.7 so that declared significant or meets convergent validity requirements. The conclusion of all indicators are declared valid for further analysis.

Table 2. Cross Loading

\begin{tabular}{crrrrr}
\hline & Firm Value & \multicolumn{1}{c}{ Solvability } & \multicolumn{1}{c}{ Profitability } & \multicolumn{1}{c}{ Liquidity } & \multicolumn{1}{c}{ Tax } \\
\hline PBV & $\mathbf{1 . 0 0 0}$ & -0.023 & -0.208 & -0.064 & 0.169 \\
DAR & -0.021 & $\mathbf{0 . 7 5 0}$ & 0.123 & -0.007 & -0.026 \\
DER & -0.024 & $\mathbf{0 . 9 6 1}$ & 0.072 & 0.070 & -0.057 \\
LTC & -0.018 & $\mathbf{0 . 9 1 5}$ & -0.033 & 0.160 & -0.082 \\
BEP & -0.238 & 0.035 & $\mathbf{0 . 7 8 5}$ & -0.006 & -0.176 \\
GPM & -0.111 & 0.016 & $\mathbf{0 . 8 4 5}$ & 0.238 & -0.204 \\
QR & -0.016 & 0.008 & 0.119 & $\mathbf{0 . 7 9 4}$ & -0.106 \\
CR & -0.086 & 0.176 & 0.112 & $\mathbf{0 . 7 1 4}$ & -0.092 \\
ETR & 0.169 & -0.072 & -0.234 & -0.132 & $\mathbf{1 . 0 0 0}$ \\
\hline
\end{tabular}

Based on the data presented in Table 2 which show the cross loading result, it can be stated that indicators used in this study have good discriminant validity in preparing their respective variables.

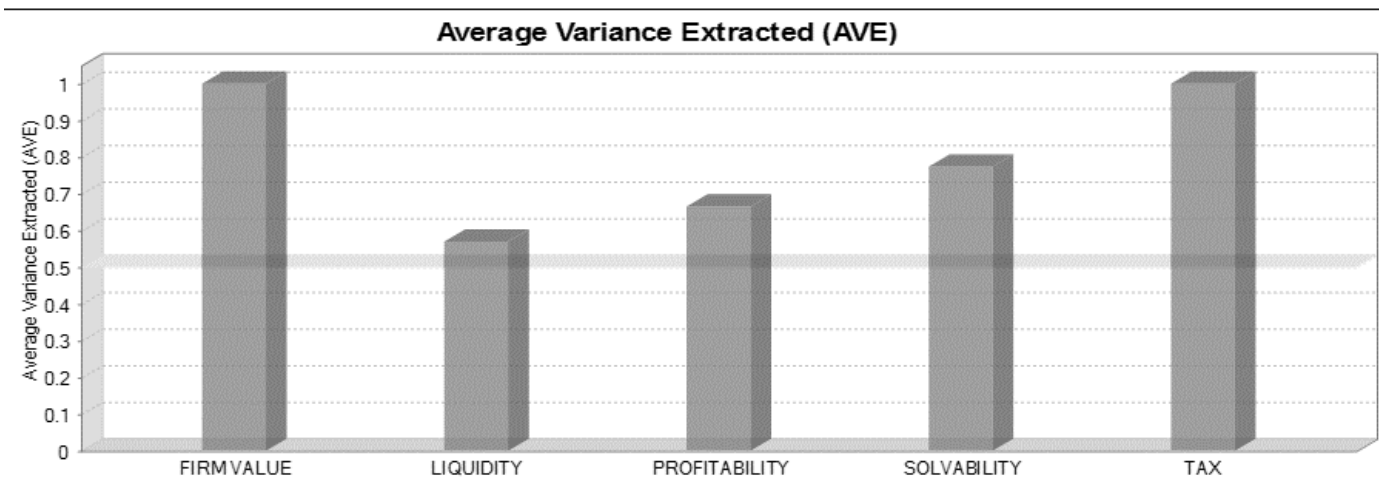

Figure 4. Average variance Extracted (AVE)

Average Variance Extracted (AVE) and correlation latent value in the table above all variable are $>0.5$ so it can be said that each indicator has been measured able to reflect on each variable validly. 
Table 3. Cronbach's Alpha and Composite Reliability

\begin{tabular}{cccc}
\hline & Cronbach's Alpha & Composite Reliability & Validality (>0.70) \\
\hline Firm Value & 1.000 & 1.000 & Valid \\
Liquidity & 0.713 & 0.726 & Valid \\
Profitability & 0.741 & 0.799 & Valid \\
Solvability & 0.873 & 0.911 & Valid \\
Tax & 1.000 & 1.000 & Valid \\
\hline
\end{tabular}

Based on the data presented in Table 3 above, it can be seen cronbach's alpha and composite reliability value of all research variables is $>0.7$. These results indicate that each variable has complied with cronbach's Alpha and composite reliability so it can be concluded that all variables have a high level of reliability.

Table 4. Inner Model

\begin{tabular}{cccc}
\hline Variable $(\mathbf{X})$ & Variable $(\mathbf{Y})$ & CI & Validity $(\mathbf{C I}>\mathbf{1})$ \\
\hline Liquidity & Tax & 1.639 & Valid \\
Solvability & Tax & 1.358 & Valid \\
Profitability & Tax & 2.634 & Valid \\
Tax & Firm Value & 1.670 & Valid \\
\hline
\end{tabular}

The second model must be testing is the inner model. Based on the results of inner model above, it can also be seen that all paths have fulfilled a significant in $95 \% \mathrm{CI}>1$. Evaluation of path coefficient is used to show how strong the effect or the influence of the independent variable is on the dependent variable. Based on the initial model, it can be said when the relationship between latent variables and others showing the numbers above 1 with an estimated parameter of $95 \%$ will be declared valid.

Furthermore, it is seen how much the strength of exogenous variables and endogenous variables which are dependent on this initial model by looking at the magnitude of the value of $\mathrm{R}$ Square on each of the endogenous variables. $\mathrm{R}^{2}$ testing is presented in Table 5 below:

Table 5. R square

\begin{tabular}{ccc}
\hline & R Square & Research Contribution \\
\hline Firm value & 0,467 & Sustainable / medium \\
Tax & 0,571 & Sustainable / medium \\
\hline
\end{tabular}

Based on the inner model scheme shown in Table 5 above, it explains the contribution of variables that affect variables in the R-Square table, the value of the R-Square Firm Value variable is 0.467 or $46.7 \%$. This means that $53.3 \%$ is influenced by other factors outside of this study. While the influence of tax with a value of $\mathrm{R}^{2}$ completed 0.571 or $57.1 \%$. This means that $42.9 \%$ is influenced by other factors outside of this study. Based on the description of the results, it shows that all variables in this model have a path coefficient with positive numbers.

$\mathrm{Q}^{2}$ value has the same meaning as determination coefficient ( $\mathrm{R}$-Square) in the regression analysis, where the higher $\mathrm{Q}^{2}$, the model can be said more suitable with the data. The $\mathrm{Q}^{2}$ Value function is to assess the amount of diversity or variation in research data on the phenomenon being studied as well as its parameter estimates. A model is considered to have a relevant predictive value if the value of $\mathrm{Q}^{2}$ is greater than zero. The magnitude of $\mathrm{Q}^{2}$ has a value with a range of $0<\mathrm{Q}^{2}<1$. The results of the calculation of the Q-Square value are as follows: 


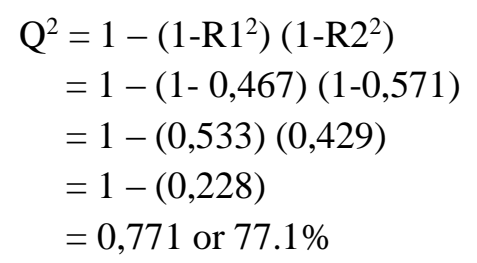

Based on the results, $\mathrm{Q}^{2}$ value is 0.771 . This shows the amount of diversity of the research data can be explained by the research model is $77.1 \%$. While the remaining $22.9 \%$ is explained by other factors outside the research model. Thus, from these results, this research model can be stated to have good goodness of fit. To find out the continuity of the proposed model in a population, the value of relationship between one variable with another variable or path coefficient value (rho) by looking at the size of the $\mathrm{O}$ (original sample) and $\mathrm{T}$ value statistics as a statement of the significance level of the relationship between one variable with other variables (the significance level taken at the 5\% error level or at $\mathrm{T}$ above 1). The research hypothesis can be declared accepted if the $P$-Values is $<0.05$. The following are the results of hypothesis testing obtained in this study through the inner model.

Table 6. T- Statistic and P-Value

\begin{tabular}{cccc}
\hline & $\begin{array}{c}\text { Original } \\
\text { Sample }\end{array}$ & T Statistic & P value $(<\mathbf{0 , 0 5})$ \\
\hline Liquidity - Tax & $-0,092$ & $1,653 * *$ & 0,049 \\
Profitability - Tax & $-0,218$ & $2,638^{* * *}$ & 0,004 \\
Solvability - Tax & $-0,055$ & 0,353 & 0,362 \\
Tax - Firm Value & 0,169 & $1,678 * *$ & 0,047 \\
\hline ***Significant at the $1 \%, * *$ Significant at the $5 \%, *$ Significant at the $10 \%$
\end{tabular}

The regression result for hypothesis 1 in Table 6 . Hypothesis 1 stated that liquidity has a negative effect on tax aggressiveness. Based on the regression result on Table 6, hypothesis 1 is supported with the low profitability can reflect companies having difficult in short-term obligations. Liquidity difficulties can lead companies to disobey tax regulations so they can lead to aggressive actions against tax corporate. The reason, companies are more concerned with maintaining cash flow than having to pay high tax. Tax savings results can be used by companies to fulfill their short-term obligations.

Trade off theory explains that tax aggressiveness is a substitute for use of debt. This means that tax aggressiveness can be substituted from use of debt because when the company does not use debt in funding company then tax is high. This happens because cost of debt incurred from the use of debt in the form of interest expense can be deduction in company profits so that company profits are small and the tax paid is also small. Companies use more debt when involved in tax aggressiveness (Kubick \& Lockhart, 2017). This affect of the company's like in capital structure, namely whether to make funding originating from capital, namely stock capital and retained earnings or from external parties in the form of debt.

According to Tiaras \& Wijaya (2017) state that tax aggressiveness is a substitute for use of debt, it can increase financial, avoid the cost of bankruptcy, audit quality, low risk of default, so can reduce the cost of debt. Company will choose the level of debt that is negatively related to tax level not debt. If the company does not use debt financing, it will cause the company use less debt and will reduce debt cost. The results of the study revealed greater the tax aggressiveness would be further reducing the cost of debt. Companies with high liquidity ratios indicate the company's ability to meet lower level requirements, which shows the company is in accordance with financial 
conditions and easily sells its assets if needed. Companies that have high liquidity ratios are called liquid companies.

Liquidity problems are one of the important problems in a company that relatively difficult to solve. Companies with high profit do not guarantee good liquidity. It because profit ratio is calculated from accounting profit divided by investment, assets, or equity, where accounting profit is obtained by accrual basis. Therefore, to measure the financial condition, in addition to profitability, another important measure is cash flow. Research conducted by provides companies that experience liquidity difficulties are likely not to comply with tax regulations and tend to avoid tax evasion. This action is carried out by the company to reduce expenditure on tax and utilize the savings made to maintain cash flow. Therefore companies that have a low liquidity ratio will tend to have a high level of corporate tax aggressiveness.

The regression result for hypothesis 2 in Table 6 . Hypothesis 2 stated that profitability has a negative effect on tax aggressiveness. Based on the regression result on Table 6, profitability in this study shows there is a significant negative for tax aggressiveness. The existence of agency theory will spur agents to increase company profits. When profits are increased, the amount of tax income will increase in accordance with increase in company profits. Agents in agency theory will try to manage their tax burden so not to reduce agent performance compensation as a result of reduced corporate profits by tax. This negative relationship pays for companies that are efficient and have high profits paying low taxes. Possible reasons are profitable companies to benefit from incentive taxes and other tax allowances for ETR replacement.

Agency theory explains things that can increase company profits. Profitability describe profit generates a company through all available resource capabilities such as sales activities, cash, capital, number of employees, number of branches, etc. Profitability is related to net income and tax income for companies (Zemzem \& Ftouhi, 2013). When profits increase, the amount of income will increase according to the increase in company profits. Companies that have a high level of profit can attract investors to invest because the management company that operational company successfully. If the company has a low level profit so investors choose not to invest in capital.

Pecking order theory explains that funding from internal capital is the most preferred funding company, therefore agents will maximize the management of their internal assets. Companies that are included in the scale of large companies will have abundant resources that can be used for certain purposes. Based on agency theory, the resources owned by the company can be used by agents to maximize agent performance compensation. Windaswari \& Merkusiwati (2018) state that companies have high profitability to report tax from companies with low profitability. The results of this study are supported by Chen et al. (2010) which proves that companies with high profitability will have the opportunity to position themselves in tax planning that increases the amount of tax expenditure. The company can reduce the amount of tax by using income tax article 4 paragraph 3 concerning non-tax objects by selecting or obtaining income that is not a tax object.

Dewinta \& Setiawan (2016), who in their research prove that a negative relationship between the ability to obtain profits and tax aggressiveness. If the company's ability to generate profits increases, the company's operating profit will also increase and tax contribution paid by the company also increases. This gives a reason for companies to oppose tax because tax take into account costs by companies. This shows that profitability plays a role in tax aggressiveness, but 
with increasing profit and tax aggressiveness increases because the company paying and reporting tax and does not take efficiency measures in pay tax.

The regression result for hypothesis 3 in Table 6 . Hypothesis 3 stated that solvability has a negative effect on tax aggressiveness. Based on the regression result on Table 6 , hypothesis in this study show that solvability have negative significant, but the test result show that negative and haven't significant effect on tax aggressiveness. It's means the level of company debt (higher or lower of debt to asset) isn't have the effect with the level of tax aggressiveness. This is because with a large solvability ratio, the company will use interest expense to reduce taxable profits which will have implications for reducing the tax. The company with high solvability tends to get strict monitoring from bondholder.

Minister finance has the authority to determine the ratio of debt to capital for the calculation of tax payable. The results of this study are in line with Darmawan \& Sukartha (2014), Dewinta \& Setiawan (2016) and Saputra \& Asyik (2017) who stated that solvability has no effect on tax aggressiveness. Company will increase with increasing returns because the effects of corporate tax shields. This is because in perfect market conditions and generally paid interest of debt can be used to increase tax income. Thus, there are two companies with the same operating profit, but one company uses debt and pays interest, while the company pays interest will pay a smaller income tax, then saving income. This ratio shows the comparison between the debt provided by the owner of the company.

Lanis \& Richardson (2011) state the higher debt value in company, the ETR value (the method used to identify the aggressiveness of a company's tax planning) will be lower. When companies rely more on financing than financing debt originating from equity for their operations, the company will have a lower ETR. This is because companies have a higher level of debt, will pay higher tax rates, making the ETR value lower. The regression result for hypothesis 4 in Table 6. Hypothesis 4 stated that firm value has a positive effect on tax aggressiveness. Based on the regression result on Table 6 , firm value has a positive effect and significant on tax aggressiveness same with hypothesis its show above, its mean that hypothesis is accepted. Its have the same research result with Dyreng, Hanlon, \& Maydew (2008), Hanlon \& Slemrod (2011), Chen et al. (2010), Chasbiandani \& Martani (2012).

Desai \& Dharmapala (2009) in their research on corporate tax aggressiveness and firm value with research samples of companies in America. The results showed that tax aggressiveness does not have a significant effect on firm value and corporate governance that is proxied by institutional ownership cannot moderate the relationship between tax aggressiveness to firm value. Hanlon \& Slemrod (2011), examine how market reactions to tax aggressiveness actions carried out by companies, state the market reacts negatively to tax aggressiveness. Companies with broader tax disclosures get better reactions and if the company is supported by good corporate governance, the market reaction will be more positive. Chen et al. (2010) examined the effect of tax aggressiveness and agency costs on firm value. The findings in this study are tax aggressiveness negatively affects firm value and tax aggressiveness also raises agency costs.

Firm value is considered as one of the responses from investors to the activities by the company. Based on the test results obtained information that corporate tax aggressiveness can actually increase firm value. This supports the results of Chasbiandani \& Martani (2012) study which states that tax aggressiveness by companies in the long term has positive effect on firm value. 
This indicates that companies pay low tax obligations have high corporate value, but these results do not fit the theory which explains that tax aggressiveness should reduce firm value. The conclusion that can be drawn from this test is use of tax aggressiveness in our society have the credibility with signaling theory because ETR have positive relationship with ETR regulation.

\section{CONCLUSION AND RECOMMENDATION}

Based on previous discussion, it can be concluded several conclusion regarding independent variables. Liquidity has negative and significant effect on tax aggressiveness. This indicates that companies with difficulties liquidity are likely not to comply with tax regulations and tend to avoid tax evasion. Solvability has negative and not significant effect on tax aggressiveness. This indicates that company will use debt as tax deduction. The greater debt, tax profit will be smaller so company conducts tax aggressiveness. Profitability has negative and significant effect on tax aggressiveness. This indicates that manufacturing companies whose finance operations by debt and tend to make tax savings. Firm value has positive and significant effect on tax aggressiveness. This indicates that management is trying to manage finances well and efficiently by minimizing tax burden so firm value will increase.

Some limitations contained in the study included. The study only examines manufacturing companies listed on the IDX in period 2007-2017 and the study only examines a number of factors that influence tax aggressiveness, such as profitability, solvability, liquidity, and firm value as the variable control. From the conclusion and limitation in this study, the implication and recommendation that can be given include: (1) future studies should add other variables outside the independent variables used in this study to obtain result that show a greater influence on tax aggressiveness in the listed companies; (2) for researchers who will conduct similar research can add years, samples, and object of research other than manufacturing companies, so that the result obtained are better; (3) future studies can use proxy tax aggressiveness other than ETR, for example Net Profit Margin (NPM), Effective Cash Tax Rate (ECTR), Tax Planning (TAXPLAN) or Book Tax Differences (BTD).

\section{REFERENCES}

Anita, F., Basri, Y., \& Julita, J. (2015). Pengaruh Corporate Social Responsibility, Leverage, Likuiditas, dan Ukuran Perusahaan terhadap Agresivitas Pajak (Studi Empiris pada Perusahaan Real Estate dan Property yang Terdaftar Di Bursa Efek Indonesia Tahun 20102013). Jurnal Online Mahasiswa Fakultas Ekonomi Universitas Riau, 2(2), 1-15.

Blouin, J. (2014). Defining and Measuring Tax Planning Aggressiveness. National Tax Journal, 67(4), 875-900.

Brigham, E. F. dan L. C. G. (2018). Intermediate Financial Management (13th edition). Sea Harbor Drive: The Dryden Press.

Chasbiandani, T., \& Martani, D. (2012). Pengaruh Tax Avoidance Jangka Panjang terhadap Nilai Perusahaan. Simposium Nasional Akuntansi (SNA).

Chen, S., Chen, X., Cheng, Q., \& Shevlin, T. (2010). Are Family Firms More Tax Aggressive Than Non-Family Firms? Journal of Financial Economics, 95(1), 41-61.

Chen, X., Hu, N., Wang, X., \& Tang, X. (2014). Tax Avoidance and Firm Value: Evidence from China. Nankai Business Review International, 5(1), 25-42. 
Connelly, B. L., Certo, S. T., Ireland, R. D., \& Reutzel, C. R. (2011). Signaling Theory: A Review and Assessment. Journal of Management, 37(1), 39-67.

Darmadi, I. N. H., \& Zulaikha. (2013). Analisis Faktor yang Mempengaruhi Manajemen Pajak dengan Indikator Tarif Pajak Efektif. Diponegoro Journal of Accounting, 2(4), 368-379.

Darmawan, I., \& Sukartha, I. (2014). Pengaruh Penerapan Corporate Governance, Leverage, ROA, dan Ukuran Perusahaan pada Penghindaran Pajak. E-Jurnal Akuntansi, 9(1), 143-161.

Desai, M. A., \& Dharmapala, D. (2009). Corporate Tax Avoidance and Firm Value. Review of Economics and Statistics, 91(3), 537-546.

Dewinta, I. A. R., \& Setiawan, P. E. (2016). Pengaruh Ukuran Perusahaan, Umur Perusahaan, Profitabilitas, Leverage, dan Pertumbuhan Penjualan terhadap Tax Avoidance. E-Jurnal Akuntansi Universitas Udayana, 14(3), 1548-1615.

Dyreng, S. D., Hanlon, M., \& Maydew, E. L. (2008). Long-Run Corporate Tax Avoidance. The Accounting Review, 83(1), 61-82.

Fama, E. F., \& French, K. R. (1998). Taxes, Financing Decisions, and Firm Value. Journal of Finance, 53(3), 819-843.

Ghozali, I. (2013). Struktural Equation Modeling: Motode Alternatif dengan PLS. Universitas Diponegoro.

Gupta, S., \& Newberry, K. (1997). Determinants of The Variability in Corporate Effective Tax Rates: Evidence from Longitudinal Data. Journal of Accounting and Public Policy, 16(1), $1-34$.

Hanlon, M., \& Slemrod, J. B. (2011). What Does Tax Aggressiveness Signal? Evidence from Stock Price Reactions to News About Tax Aggressiveness. SSRN Electronic Journal.

Jensen, M. C., \& Meckling, W. H. (1976). Theory of The Firm: Managerial Behavior, Agency Costs and Ownership Structure. Journal of Financial Economics, 3(4), 305-360.

Kamila, P. A. (2014). Analisis Hubungan Agresivitas Pelaporan Keuangan dan Agresivitas Pajak pada Saat Terjadinya Penurunan Tarif Pajak. Finance and Banking Journal, 16(2), 228-245.

Kubick, T. R., \& Lockhart, G. B. (2017). Corporate Tax Aggressiveness and The Maturity Structure of Debt. Advances in Accounting, 36, 50-57.

Lanis, R., \& Richardson, G. (2011). The Effect of Board of Director Composition on Corporate Tax Aggressiveness. Journal of Accounting and Public Policy, 30(1), 50-70.

Modigliani, F., \& Miller, M. H. (1958). The Cost of Capital, Corporation Finance and the Theory of Investment. The American Economic Review, 48(3), 261-297.

Nugraha, N. B., \& Meiranto, W. (2015). Pengaruh Corporate Social Responsibility, Ukuran Perusahaan, Profitabilitas, Leverage dan Capital Intensity terhadap Agresivitas Pajak. Diponegoro Journal of Accounting.

Putra, P. D., Syah, D. H, \& Sriwedari, T. (2018). Tax Avoidance: Evidence of as A Proof of Agency Theory and Tax Planning. International Journal of Research \& Review, 5(9), 52-60.

Ross, S. A. (1977). Determination of Financial Structure: The Incentive-Signalling Approach. Bell J Econ, 8(1), 23-40.

Saputra, M. D. R., \& Asyik, N. F. (2017). Pengaruh Profitabilitas, Leverage, dan Corporate Governance terhadap Tax Avoidance. Jurnal Ilmu dan Riset Akuntansi, 6(8), 1-19. 
Sari, D. K., \& Martani, D. (2010). Karakteristik Kepemilikan Perusahaan, Corporate Governance, dan Tindakan Pajak Agresif. Journal IFRS Convergence and Application Faculty of Economics Universitas Indonesia.

Sartori, N. (2010). Corporate Governance Dynamics and Tax Compliance. International Trade and Business Law Review.

Sukmawati, F., \& Rebecca, C. (2016). Pengaruh Likuiditas dan Leverage terhadap Agresivitas Pajak Perusahaan. Conference on Management and Behavioral Studies.

Suyanto, K. D., \& Supramono. (2012). Likuiditas, Leverage, Komisaris Independen, dan Manajemen Laba terhadap Agresivitas Pajak Perusahaan. Journal of Finance and Banking, $16(2)$.

Tiaras, I., \& Wijaya, H. (2017). Pengaruh Likuiditas, Leverage, Manajemen Laba, Komisaris Independen dan Ukuran Perusahaan terhadap Agresivitas Pajak. Jurnal Akuntansi, 19(3), 380-397.

Timothy, Y. C. K. (2010). Effects of Corporate Governance on Tax Avoidance. Hong Kong Baptist University.

Waegenaere, A. D., Sansing, R., \& Wielhouwer, J. L. (2013). Financial Accounting Effects of Tax Aggressiveness: Contracting and Measurement. Contemporary Accounting Research, $32(1), 223-242$.

Widjaja, D.I., Djumena, S., \& Yuniarwati. (2017). Faktor-Faktor yang Mempengaruhi Agresivitas Pajak pada Perusahaan Manufaktur yang Terdaftar di BEI 2013-2015. Jurnal Muara Ilmu Ekonomi dan Bisnis, 1(1), 125-134.

Windaswari, K. A., \& Merkusiwati, N. K. L. A. (2018). Pengaruh Koneksi Politik, Capital Intensity, Profitabilitas, Leverage dan Ukuran Perusahaan pada Agresivitas Pajak. E-Jurnal Akuntansi, 23(3), 1980-2008.

Yusuf, M. M., Yunus, F. M., \& Supaat, N. Z. L. M (2013). Determinants of Capital Structure in Malaysia Electrical and Electronic Sector. International Journal of Social, Behavioral, Educational, Economic, Business and Industrial Engineering, 7(6), 1514-1519.

Zemzem, A., \& Ftouhi, K. (2013). The Effects of Board of Directors' Characteristics on Tax Aggressiveness. Research Journal in Finance and Accounting.

Zimmerman, J. L. (1983). Taxes and firm size. Journal of Accounting and Economics, 5(3), 119-149. 